Pesq. Vet. Bras. 35(6):590-598, junho 2015

DOI: $10.1590 / \mathrm{S} 0100-736 \mathrm{X} 2015000600018$

\title{
Isolation, expansion and differentiation of cellular progenitors obtained from dental pulp of agouti (Dasyprocta prymnolopha Wagler, 1831) ${ }^{1}$
}

\author{
Yulla K.P. de Carvalho², Napoleão M. Argôlo-Neto³ ${ }^{3}$ Carlos E. Ambrósio ${ }^{4}$, \\ Lilian de Jesus de Oliveira ${ }^{4}$, Andressa R. da Rocha ${ }^{2}$, Janete B. da Silva ${ }^{2}$, \\ Maria Acelina M. de Carvalho ${ }^{2}$ and Flávio R. Alves ${ }^{2 *}$
}

\begin{abstract}
Carvalho Y.K.P., Argôlo-Neto N.M., Ambrósio C.E., Oliveira L.J., Rocha A.R., Silva J.B., Carvalho M.A.M. \& Alves F.R. 2015. Isolation, expansion and differentiation of cellular progenitors obtained from dental pulp of agouti (Dasyprocta prymnolopha Wagler, 1831). Pesquisa Veterinária Brasileira 35(6):590-598. Departamento de Morfisiologia Veterinária, Universidade Federal do Piauí, Campus Universitário Ministro Petrônio Portella, Bairro Ininga, Teresina, PI 64049-550, Brazil. E-mail: flavioribeiro@ufpi.edu.br

The study aimed to isolate, expand, differentiate and characterize progenitor cells existent in the dental pulp of agouti. The material was washed with PBS solution and dissociated mechanically with the aid of a scalpel blade on plates containing culture medium D-MEM/F-12, and incubated at $5 \% \mathrm{CO}^{2}-37^{\circ} \mathrm{C}$. The growth curve, CFU assay, osteogenic/ adipogenic differentiation and characterization were obtained from the isolation. The cells began to be released from the explant tissue around the 7th day of culture. By day 22 of culture, cells reached $80 \%$ confluence. At the UFC test, 81 colonies were counted with 12 days of cultivation. The growth curves before and after freezing showed a regular growth with intense proliferation and clonogenic potential. The cell differentiation showed formation of osteoblasts and fat in culture, starting at 15 days of culture in a specific medium. Flow cytometry (FACs) was as follows: CD34 (positive), CD14 (negative), CD45 (negative), CD73 (positive), CD79 (negative), CD90 (positive), CD105 (positive), demonstrating high specificity and commitment of isolated cells with mesenchymal stem cells strains. These results suggest the existence of a cell population of stem cells with mesenchymal features from the isolated tissue in the explants of agouti dental pulp, a potential model for study of stem cell strains obtained from the pulp tissue.
\end{abstract}

INDEX TERMS: Dasyprocta prymnolopha, MSC from dental pulp, cell culture, cell differentiation, cell biology.

RESUMO.- [Isolamento, expansão e diferenciação de progenitors celulares obtidos da polpa dentária de cutia (Dasyprocta prymnolopha Wagler, 1831).] Isolation, expansion and differentiation of cellular progenitors obtained from dental pulp of agouti (Dasyprocta prymnolopha Wagler, 1831). Este estudo teve como objetivo isolar,

\footnotetext{
${ }^{1}$ Received on September 11, 2014.

Accepted for publication on March 8, 2015.

${ }^{2}$ Departamento de Morfofisiologia Veterinária, Universidade Federal do Piauí (UFPI), Teresina, PI 64049-550, Brazil. *Corresponding author: flavioribeiro@ufpi.edu.br

${ }^{3}$ Departamento de Zootecnia, UFPI, Bom Jesus, PI 64900-000, Brazil.

${ }^{4}$ Departamento de Medicina Veterinária, Universidade de São Paulo (USP), Pirassununga, SP 13635-900, Brazil.
}

expandir, diferenciar e caracterizar células progenitoras existentes na polpa dentária de cutia. 0 material foi lavado em solução de PBS e dissociado mecanicamente, com o auxílio de uma lâmina de bisturi, em placas contendo meio de cultura D-MEM/F-12, e incubadas em $5 \%$ de $\mathrm{CO} 2-37^{\circ} \mathrm{C}$. A curva de crescimento, o ensaio de $\mathrm{CFU}$, a diferenciação osteogênica/adipogênica e a caracterização foram obtidas a partir do isolamento. As células começaram a ser liberadas, a partir do explante, em torno do sétimo dia de cultura. A partir do $22^{\circ}$ dia, as células atingiram $80 \%$ de confluência. No teste para UFC, 81 colônias foram contadas aos 12 dias de cultivo. As curvas de crescimento pré- e pós-congelamento apresentaram crescimento regular, com intensa proliferação e potencial clonogênico. A diferenciação das 
células mostrou a formação de osteoblastos e de células de gordura, a partir de 15 dias de cultura em meio específico. A citometria de fluxo (FACS) apresentou-se como segue: CD34 (positivo), CD14 (negativo), CD45 (negativo), CD73 (positivo), CD79 (negativo), CD90 (positivo), CD105 (positivo), demonstrando a grande especificidade e comprometimento das células isoladas com linhagens de células-tronco mesenquimais. Estes resultados sugerem a existência de uma população de células-tronco mesenquimais isolada a partir de explantes da polpa dentária cutia, um modelo potencial para o estudo de linhagens de células-tronco obtidas a partir do tecido pulpar.

TERMOS DE INDEXAÇ̃̃O: Dasyprocta prymnolopha, MSC da polpa dentária, cultivo celular, diferenciação celular, biologia celular.

\section{INTRODUCTION}

Dental pulp (DP) contains mesenchymal stem cells that are relatively easy to obtain and propagate compared to other niches in the organism (Sloan \& Smith 2007, Kadar et al. 2009, Karaoz et al. 2010). In vitro, these cells can differentiate into odontoblasts, osteoblasts, endothelial cells, smooth muscle, adipocytes, chondrocytes, and neurons (Kerkis et al. 2006, Ulmer et al. 2010). Mesenchymal stem cells were isolated from dental pulp (MSCDP) in several experiments, which demonstrated high proliferation power and showed that they are multipotent and capable of self-renewal and high plasticity (Miura et al. 2003, Kerkis et al. 2006, Monteiro et al. 2009). Atari et al. (2011) obtained mesenchymal stem cells from dental pulp of third molars and found that the success in establishing specialized cell types contributed to their use in potential applications in biological research and regenerative medicine.

The immunophenotypic study of immature cells of the dental pulp of human deciduous teeth revealed expression of embryonic markers such as Oct-4 and Nanog and the positive expression of surface markers proper to mesenchymal stem cells such as CD105, CD73 and CD13 (Kerkis et al. 2006) and in addition, other positive markers such as CD44, CD90 and CD166, and negative markers such as CD34, CD31 and CD45 have been observed (Agha-Hosseini et al. 2010).

Small rodents are often used as an animal model to assist in comprehending the behavior of stem cells in vitro (Balic et al. 2010) and in vivo (Otsu et al. 2012). The agouti is a rodent that has been extensively studied (Assis-Neto et al. 2003, Menezes et al. 2003, Azevêdo et al. 2008) and which shows biological and physiological characteristics favorable for use in experimental research as a animal model (Fortes et al. 2005, Conde-Júnior et al. 2012, Rocha et al. 2012). Bone marrow mononuclear cells of this animal were injected to treat induced renal injury (Cabral et al. 2012) and in culture undifferentiated cells were obtained through the isolation and expansion by several passages (Rocha et al. 2012). Despite these preliminary studies involving agouti stem cells, there are few reports in the literature, and therefore, in order to verify the potential of mesenchymal stem cells from other niches of this animal, the objective of the present study was to characterize the behavior of stem cells obtained from incisor tooth pulp in culture.

\section{MATERIALS AND METHODS}

\section{Animals}

A total of four 1 to 2-year-old male agouti (Dasyprocta prymnolopha Wagler, 1831) were used. The animals came from the Center for the Study and Preservation of Wild Animals (NEPAS), Agricultural Sciences Center (CCA) of the, Federal University of Piauí, after routine disposal, because of humane slaughter conducted periodically by NEPAS for purposes of population control (withdrawal of old-aged animals and with severe traumatic injuries after territorial fighting).

After slaughter, the selected animals were submitted to radiographic examination of dental arches and only animals with healthy teeth were included in the study. The exclusion criteria were: animals showing infectious oral lesions of any order (acute or chronic), pathological pulp changes, periodontal alterations, or dental pulp with internal or external resorption. After this phase, a lower incisor tooth was extracted and taken to the Morphological Research in Animal Science Laboratory-CCA/UFPI. The carcasses were returned to follow the routine disposal of NEPAS. All activities performed were authorized by the Ethics Committee on Animal Experimentation, UFPI, Protocol 044/11; SISBIO/IBAMA n.29418-1.

\section{Radiographic examination}

To carry out the radiographic examinations the animals were positioned with the forelimbs pulled cranially and the pelvic limbs pulled caudally in the lateral decubitus position on a table for radiological procedures. Radiographs were obtained in latero-lateral (LL) projections of the skull, in the region of the mandibular incisors. For this, a mobile x-ray machine INTECAL CR-7 was used, installed in the Department of Imaging Diagnosis of the Veterinary Hospital of the Federal University of Piauí. The device was calibrated with focus-film distance of $1 \mathrm{~m}$ and exposure techniques of $45 \mathrm{kVp}$ and $0.1 \mathrm{mAs}$. Images were acquired in $18 \times 24 \mathrm{~cm}$ metal radiographic chassis filled by radiographic films (Kodak ${ }^{\circledR}$, Brazil). The films were developed and fixed in a Microtec MX-automatic processor. The radiographs were digitized and documented for further evaluation.

\section{Obtaining mesenchymal stem cells from the dental pulp of agouti (MSCDP)}

The collected lower incisor teeth were immersed in a solution of $0.12 \%$ chlorhexidine for 5 minutes. After that, in a laminar flow environment, the pulp chamber was accessed using diamond bur 1012, compatible with the pulp chamber, then a Hedstroem n. 15 or 20 file to remove the dental pulp. The collected material was washed twice in sterile phosphate buffer solution (PBS, $0.01 \mathrm{M}, \mathrm{pH}$ : 7.4) supplemented with penicillin-streptomycin at $3 \%(100 \mathrm{U} / \mathrm{ml}$ penicillin, $100 \mu \mathrm{g} / \mathrm{mL}$ streptomycin) (Fig.1a).

Afterwards, the tissue was mechanically dissociated with the aid of a scalpel blade into a $35 \mathrm{~mm}$ Petri dish con- 

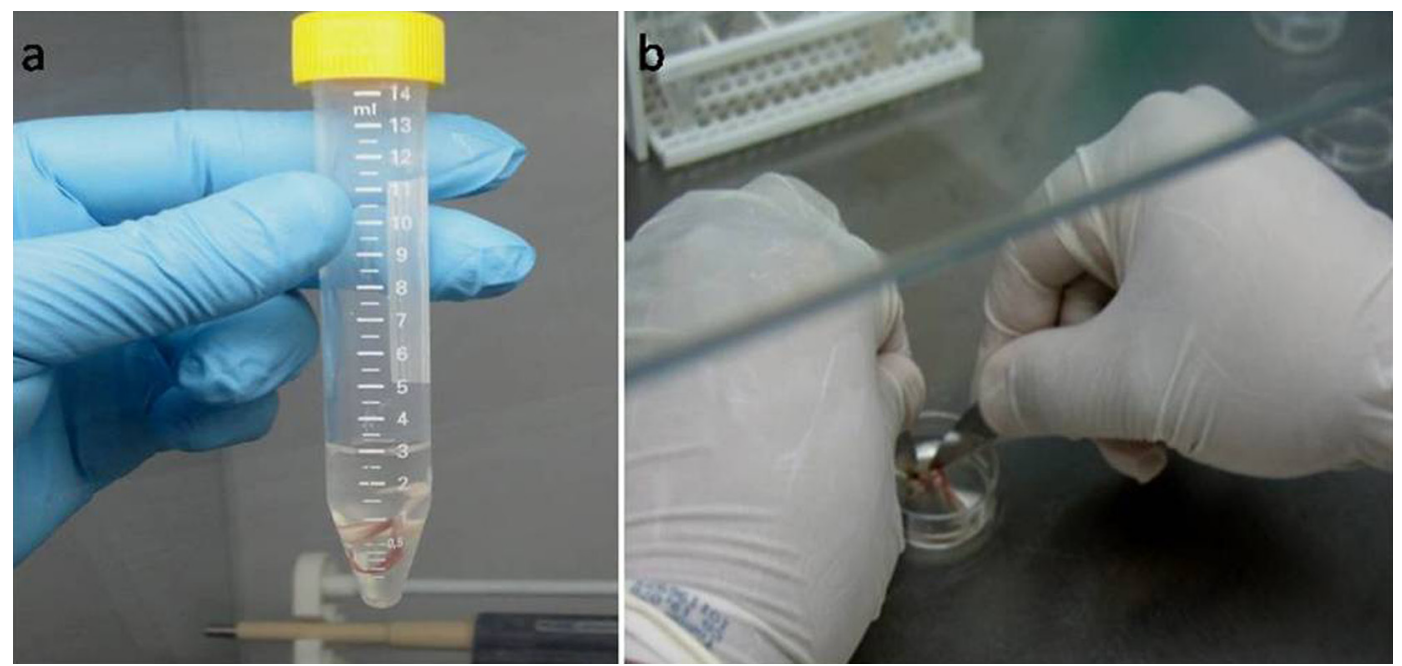

Fig.1. (a) Pulp tissue after collection and access from the pulp chamber soaked in PBS. Mechanical dissociation process of pulp tissue. Pulpal tissue soaked in PBS. (b) Pulp tissue undergoing mechanical dissociation in complete basal culture medium D-MEM/F-12 (Invitrogen, Cat №10565-018) supplemented with 20\% fetal bovine serum (Invitrogen Corporation, №16000-044, 1000ml), 1\% penicillin-streptomycin, $1 \%$ L-glutamine and 1\% nonessential amino acids.

taining "complete basal" culture medium D-MEM/F-12 (Invitrogen, Cat №10565-018) supplemented with 20\% fetal bovine serum (Invitrogen Corporation, № 16000-044, $1000 \mathrm{ml}), 1 \%$ penicillin-streptomycin, $1 \%$ L-glutamine and $1 \%$ nonessential amino acids (Figure 1b) and transferred to $25 \mathrm{~cm}^{2}$ culture flasks (Fig.1b). Subsequently the material was incubated in a incubator containing atmosphere of $\mathrm{CO}_{2}$ $-5 \%$ at $37^{\circ} \mathrm{C}$. The culture was monitored daily to assess cell growth and the medium was changed every three days. The cultured cells were subcultured when they reached $80 \%$ confluence to prevent cell differentiation.

\section{Assay Colony Forming Units (CFU)}

To evaluate the number of colonies of mesenchymal progenitor cells, tests were performed to identify Colony Forming Units.

Mechanically dissociated pulp tissue from the agouti (Dasyprocta prymnolopha Wagler, 1831) was placed in a $25 \mathrm{~cm}^{2}$ flask containing complete basal medium. The culture was evaluated daily and the medium was changed every three days for 12 days of culture, when interaction and the presence of cell colonies were observed regularly distributed in the culture flask. Thereafter the culture was washed three times with PBS solution to completely eliminate traces of culture medium, $3 \mathrm{~mL}$ of $4 \%$ paraformaldehyde were then added and incubated at $37^{\circ} \mathrm{C}$ for 30 minutes to fix the colonies. After this time, the $4 \%$ paraformaldehyde was removed and the culture stained with Giemsa and then incubated again at $37^{\circ} \mathrm{C}$ for 10 minutes. The flask was washed with distilled water to remove excess dye and thereby the analysis and counting of the colonies were possible.

\section{Cell growth curve}

For the composition of the growth curve, cells in the third passage (P3) were plated at an initial concentration of $1 \times 10^{5}$ cells $/ \mathrm{ml}$ in $25 \mathrm{~cm}^{2}$ flasks in a total of 20 flasks with this initial concentration. This was followed by trypsinization of one flask per day using $0.25 \%$ Trypsin/EDTA and the existent cell concentration was calculated until all flasks were trypsinized over 20 days. The culture medium was changed every three days in the flasks that were waiting for trypsinization. The values concerning the number and cell concentration were tabulated to make a chart, characterizing a cell growth curve.

To calculate the cell concentration, an aliquot of $10 \mu \mathrm{L}$ of cell suspension was taken to the hemocytometer and observed under an optical microscope (10X lens). The concentration was determined by counting cells in four diagonal fields, and the total number of live cells, multiplied by $10^{4}$ (camera depth and per $\mathrm{mL}$ correction), this value was divided by the number of counted quadrants of the hemocytometer, as previously described by Meirelles and Nardi (2003).

\section{Cell freezing}

To freeze the cells from the cell culture, the cells of the dental pulp (CDP) in the second passage (P2) were first dissociated by $0.25 \%$ enzyme trypsin/EDTA (Invitrogen, Cat №25200-114). The "pellet" of cells was resuspended rapidly in freezing medium. The medium concentration used was 45\% D-MEM/F-12 (Invitrogen, 10313-039) supplemented with $45 \%$ Fetal Bovine Serum (Invitrogen Corporation, №16000-044, $1000 \mathrm{ml}$ ), 10\% DMSO (Vetec-cat. Cat. №590).

The cells were placed in cryotubes (at a concentration of $1 \times 10^{6}$ cells $/ \mathrm{ml} /$ cryotube), and then transferred to a freezer at $-80^{\circ} \mathrm{C}$ overnight. After 24 hours, the cryotubes were stored in liquid nitrogen at $-196^{\circ} \mathrm{C}$.

\section{Post-freeze cell growth curve}

For the composition of the post-freeze growth curve, the cells previously stored in liquid nitrogen were unfrozen and centrifuged with D-MEM/F-12 basal culture medium 
(Invitrogen, Cat $\mathrm{N}^{\circ}$. 10565-018) supplemented with 20\% bovine fetal serum (Invitrogen Corporation, №16000-044, $1000 \mathrm{ml}$ ), $1 \%$ penicillin-streptomycin, $1 \%$ L-glutamine and $1 \%$ nonessential amino acids, 3 times at $1000 \mathrm{rpm}$ rotation for 5 minutes to complete washing and elimination of any freezing medium still present.

The obtained cell suspension was plated in a $25 \mathrm{~cm}^{2}$ flask and then incubated in $\mathrm{CO}_{2}-5 \%$ at $37^{\circ} \mathrm{C}$ atmosphere. The culture was monitored daily to assess cell growth and the medium was changed every three days. Cultured cells were maintained in culture until $80 \%$ confluence was reached to prevent cell differentiation. Then the growth curve was prepared, following the protocol previously described for making the pre-freezing curve.

\section{Flow cytometry (FACs)}

Cells were subjected to flow cytometry in the fourth passage (P4) to ensure a sufficiently undifferentiated cell population for their characterization by analyzing the expression of membrane proteins by flow cytometry. Flow cytometry was performed using the Guava EasyCyte System (Guava Technologies ${ }^{\circledR}$, USA) with a blue laser (488nm). The cells were trypsinized then centrifuged at $1200 \mathrm{rpm}$ for 5 minutes and resuspended in PBS at a concentration of $1 \times 10^{5}$ cells $/ \mathrm{mL}$ using $10^{5}$ cells/tube, diluted equally and resuspended in $200 \mu \mathrm{l}$ PBS, for the subsequent addition of each antibody in the dark for 45 minutes at room temperature. The cells were then washed three times with PBS and resuspended in $0.20 \mathrm{ml}$ cold PBS. For samples incubated with unconjugated antibodies, the secondary antibody anti-mouse PE was used. The samples were incubated for 15 minutes, washed three times with PBS and resuspended in $0.20 \mathrm{ml}$ cold PBS. Cell viability was assessed using propidium iodide dye $(20 \mathrm{ug} / \mathrm{ml})$ that marks cells with loss of plasma membrane integrity.

The flow cytometer was calibrated using unmarked cells. Cells were separated by forwardscatter to remove debris. To eliminate a possible autofluorescence, the parameters were adjusted so as to remove any contribution of the unmarked cells. For each sample at least 9000 events were counted. The markers: CD34, CD14, CD45, CD73, CD79, CD90, CD105 were analyzed.

\section{Cell differentiation in vitro}

Considering the new types of products available on the market for induction of differentiation in vitro, this experiment sought to test a commercial product StemPro® kit (Invitrogen, São Paulo, Brazil), a kit used to induce differentiation of cells obtained from human tissues. Thus, we tested this kit to induce adipogenic and osteogenic differentiation of stem cells from agouti dental pulp. The acquired media was manipulated according to the manufacturer's instructions (data sheet).

\section{Adipogenic and osteogenic differentiation}

The previously cultured CDP were plated in two six-well plates at an initial density of $10^{5}$ cells $/ \mathrm{mL}$ each well, with "complete basal" culture medium. The plated cells remained in the incubator overnight. Cell expansion was obser- ved until $70 \%$ confluence. After this time, the culture medium was changed in three of the wells to the osteogenic differentiation induction medium (StemPro ${ }^{\circledR}$ Osteogenesis Differentiation Kit, Life Technologies, Brazil) in one of the culture plates. For the other one, the basal culture medium was substituted in three of the wells with adipogenic differentiation medium (StemPro ${ }^{\circledR}$ Adipogenic Differentiation Kit, Life Technologies, Brazil), and three wells were maintained on each plate as negative control.

The cell differentiation medium was changed every three days, depending on the $\mathrm{pH}$ changes in the culture. Twenty-one days after beginning the protocol, both adipogenic and osteogenic differentiation culture media were removed and the culture fixed in $4 \%$ paraformaldehyde. The culture submitted to osteogenic differentiation was stained with Alizarin Red (Sottile et al. 2003), to observe intracellular calcium deposit, red stained. The culture submitted to adipogenic differentiation was directly assessed under light microscopy to highlight the presence of dispersed fat vacuoles in the cell cytoplasm and cellular morphology typical of adipocytes.

\section{RESULTS}

Isolation and expansion of mesenchymal progenitors dental pulp of agouti (Dasyprocta prymnolopha Wagler, 1831)

In the early days of cultivation a large amount of rounded cells was observed in suspension that were present due to the mechanical decoupling of the pulp tissue. These were eliminated in the first washings.

The first adherent cells released by the explant tissue were observed from the seventh day of cell culture, some with rounded morphology which gradually elongated becoming fusiform and others that presented themselves as fusiform, arranged around the adjacent pulp tissue.

The culture became mostly homogenous, from the $10^{\text {th }}$ day of culture, showing fibroblastlike-cell morphology (Fig.2a,b). The establishment of a cell monolayer with well defined substrate occurred by the 22 nd day of culture. At this time, the culture showed elongated cells arranged in parallel and many adopted typical radial positioning (confluence) by taking $80 \%$ of the area of a flask of $25 \mathrm{~cm}^{2}$ (Fig.2c).

After this time the first passage (P1) of the cells was made, which were subcultured in two $25 \mathrm{~cm}^{2}$ flasks and when the desired confluence was reached, the contents of each of these flasks was peaked to $75 \mathrm{~cm}^{2}$ flasks, thus forming second passage (P2) of the cells.

Regardless of enzymatic dissociation, cells preserved their growth behavior, thus maintaining fibroblastoid characteristic and growth by monolayer. These cells were expanded continuously for seventeen passages (P17) and kept in culture for ninety days.

\section{Colony forming units (CFU) assay}

Study of the Colony Forming Units showed that the PCD obtained are capable of forming groups of fibroblast cells in colony form.

At the end of twelve days of cultivation, and soon after 
fixing and staining the culture with Giemsa stain, a total of eighty-one colonies of mesenchymal progenitor cells was counted. The cells maintained their fibroblastlike-cell characteristic. Moreover, it was possible to check the tendency to form colonies and intense cell-to-cell interaction, showing intense basophile staining (Fig.3). Only those colonies with more than twenty grouped cells were considered for counting. The medium was changed every three days until the end of the experiment.

\section{Pre-and post-freeze cell growth curve}

The study of the growth curve allowed analysis of the proliferative behavior of cells in culture over twenty days. Three stages with well-defined characteristics were identified. The initial phase called "Lag", from the first to third day, was characterized by no significant growth and cell proliferation at a concentration of about $1 \times 10^{5} \mathrm{cel} / \mathrm{mL}$. In the "Log" phase, from the fourth to eleventh day of culture, there was an exponential cell growth, reaching a concentration of $3.0 \times 10^{6} \mathrm{cel} / \mathrm{mL}$. From the eleventh until the last day of the curve, the cells showed a lower rate of proliferation with cell density decreasing by $1 \times 10^{6}$, designated the "Plateau" phase.

The post-freeze growth curve showed characteristics similar to those of cells from the primary culture (before fre- ezing). Well-defined Lag, Log and Plateau phases were observed. The highest rate of cell density was observed on the tenth day of culture, reaching a concentration of $2.74 \times 10^{6}$ $\mathrm{cel} / \mathrm{mL}$, and then concentrations declined successively until the $20^{\text {th }}$ day of culture and there was, at this time, a small growing peak before they reached senescence (Fig.4).

\section{Flow cytometry (FACs)}

The progenitor cells isolated from agouti dental pulp were characterized by analyzing the expression of 07 membrane proteins (CD34, CD14, CD45, CD73, CD79, CD90, CD105) by flow cytometry. The cell viability was approximately $96 \%$.

The dental pulp cells undergoing flow cytometry in passage 4 showed expression of markers as shown in Figures 5 and 6.

\section{Osteogenic differentiation}

Osteogenic differentiation was induced for 21 days and the differentiation medium was changed every three days. During the first ten days the cells showed continuous growth and fibroblastoid morphology. From the eleventh day in culture onwards, changes were observed in their format and proliferation, large cells in a variety of shapes, generally cuboidal or slightly elongated, with
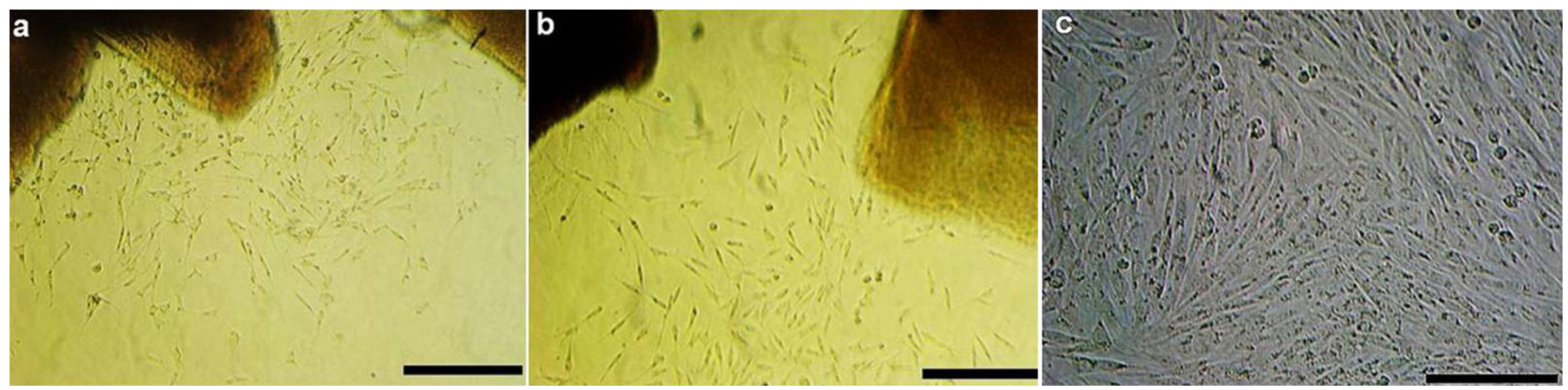

Fig.2. Cells isolated from agouti dental pulp. (a,b) Pulp tissue in culture after obtaining the adhesion of the explant to the culture flask from the 10 days of culture. Note the presence of cells with fibroblastoid characteristic adhered adjacent to tissue fragment. (c) Cell confluence after 22 days of cultivation. Note the elongated aspect of the cells and the radial pattern adopted from a central cell group. At this point the culture was subjected to dissociation and sub-cultured into other two $25 \mathrm{~cm}^{2}$ flasks to prevent spontaneous differentiation. (a,b) Bars: $100 \mu \mathrm{m},(\mathbf{c})$ Bar: $50 \mu \mathrm{m}$.
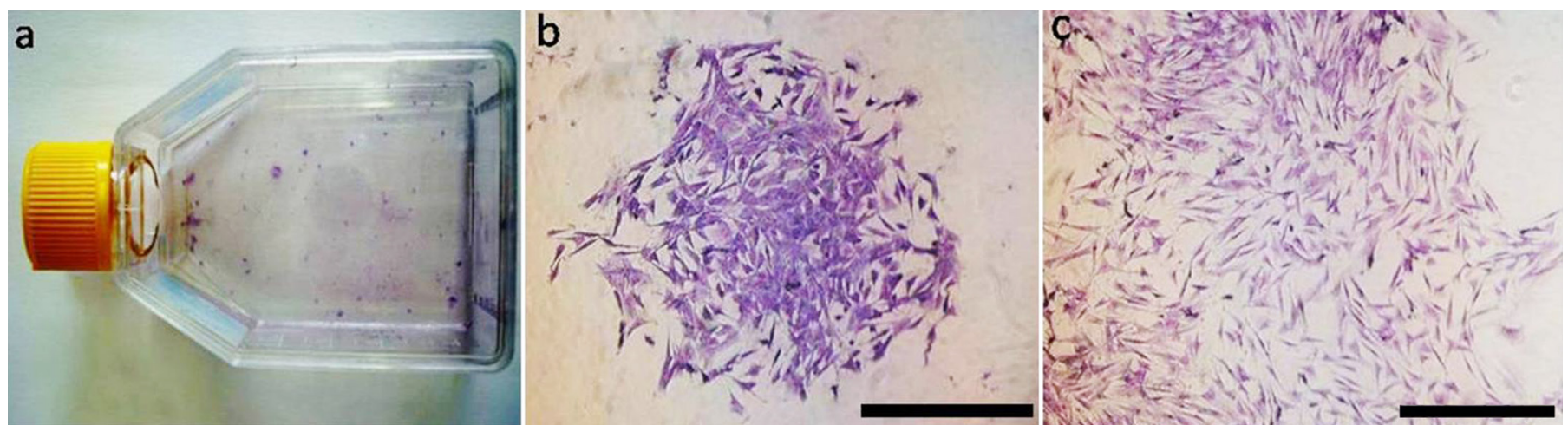

Fig.3. Isolated cells from agouti dental pulp after the test to obtain Colony Forming Units (CFU's). (a) The overview of a $25 \mathrm{~cm}^{2}$ flask after staining with Giemsa. Note the presence of more intense (basophilic) circular markings adhered to the bottom of the flask (colonies). (b) The view of a cell colony stained by Giemsa. It is noteworthy the characteristic aggregate and the evident cell-to-cell interaction. (c) Panoramic view of the colonies obtained from the test for UFCs. (b) Bars: $50 \mu \mathrm{m}$, (c) Bar: $100 \mu \mathrm{m}$. 


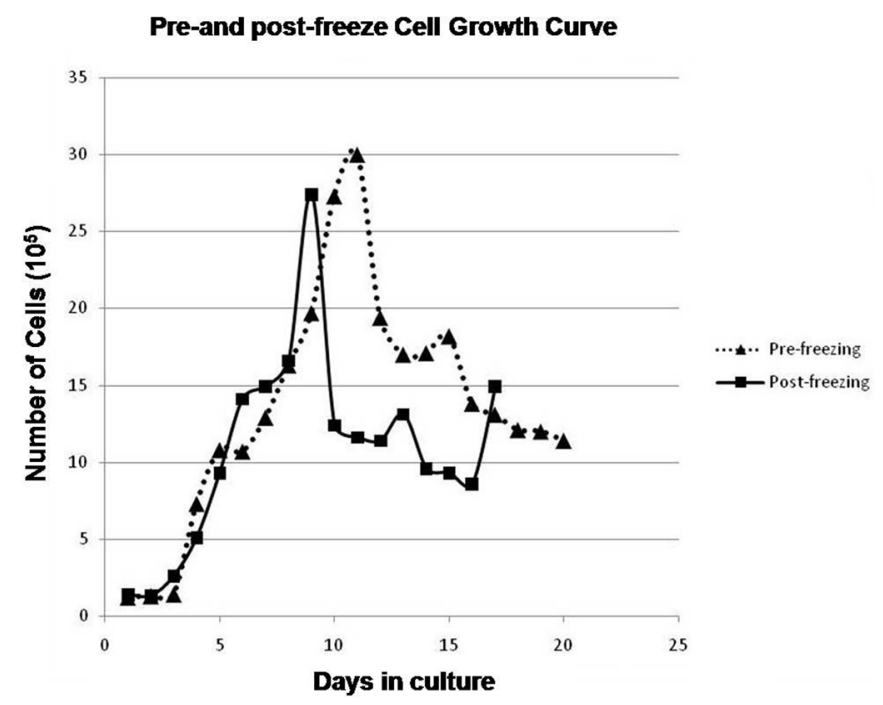

Fig.4. Pre-and post-freezing growth curve of isolated cells from agouti dental pulp, demonstrating their basal metabolic activity and behavior in culture, in different cell growth phases.
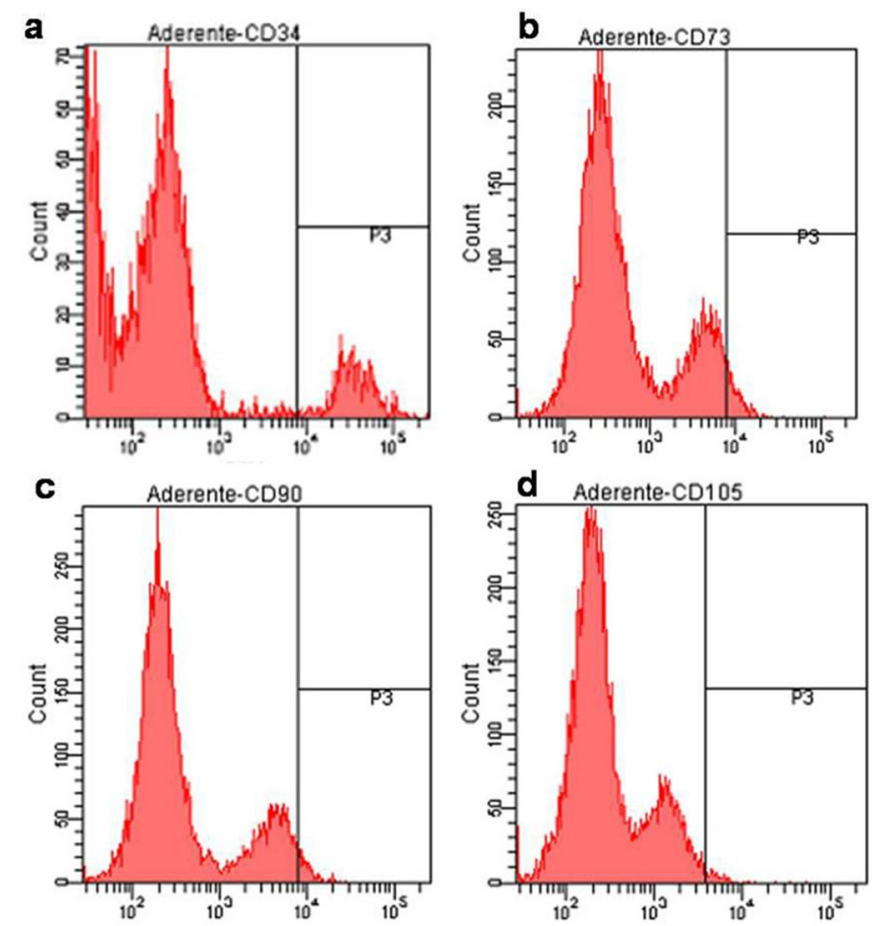

Fig.5. (a-d) Flow cytometry of progenitor cells obtained from agouti dental pulp for the markers for mesenchymal stem cells lineages. The cell population studied was found to be moderately positive for the expression of the markers studied, (a) with a clearer expression of CD34.

a spherical core located in the central region of the cytoplasm. The progenitors acquired morphology similar to osteoblasts in $90 \%$ of the culture at the end of 21 days. After staining, the nucleus appeared with a burgundy red tone and the cytoplasm was more basophilic and well defined, with presence of calcium deposits within the cells (Fig.7).

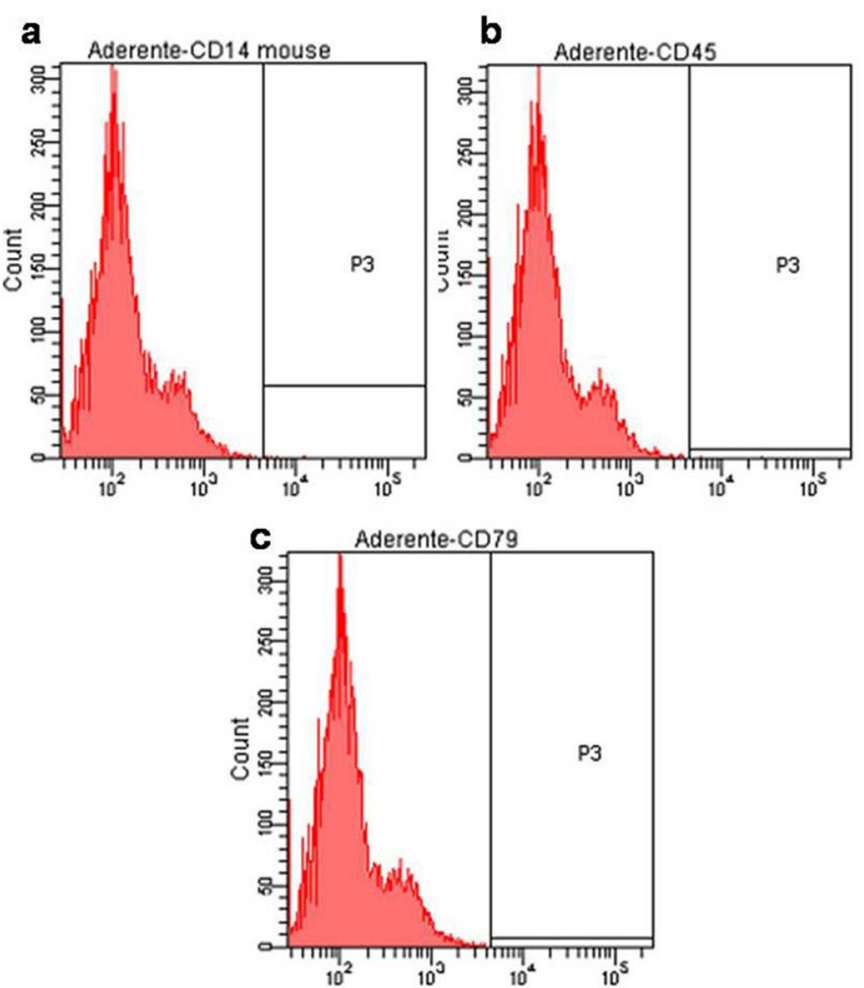

Fig.6. Flow cytometry of progenitor cells obtained from agouti dental pulp for markers for hematopoietic lineages. The cell population studied was moderately negative for the expression of the markers studied.

\section{Adipogenic differentiation}

The adipogenic differentiation followed a protocol similar to that used for osteogenic differentiation, over a period of 21 days, with successive culture medium changes (differentiation medium) every three days.

The cells grew slowly during the first week of culture. From the second week onwards, modification increased in the initial cell morphology. Following the third week of culture, cells were observed with "sprawling" morphology showing a cytoplasm containing fat birefringent granules. This situation continued until the end of 21 days differentiation, when the cultures were fixed in $4 \%$ paraformaldehyde, for subsequent evaluation by light microscopy.

Differentiated cells revealed the presence of clusters of fat (droplets) filling the cell cytoplasm. Attention was drawn to the cuboid aspect of some cells whose morphology resembled that of typical fat cells (Fig.8).

\section{DISCUSSION}

Although there are protocols using enzymatic dissociations and still associated to mechanical dissociation in the literature (Gronthos et al. 2000, Gronthos et al. 2002), we chose to submit the collected material to the least stress possible by doing only a mechanical decoupling. For the isolated cultures, although they underwent a quiescent phase (seven days), after this period they demonstrated a change in morphology and growth adjacent to the explant tissue. Balic \& Mina (2010), also observed that these cells proliferate rapidly and can reach confluence in a few days. Further, Gron- 


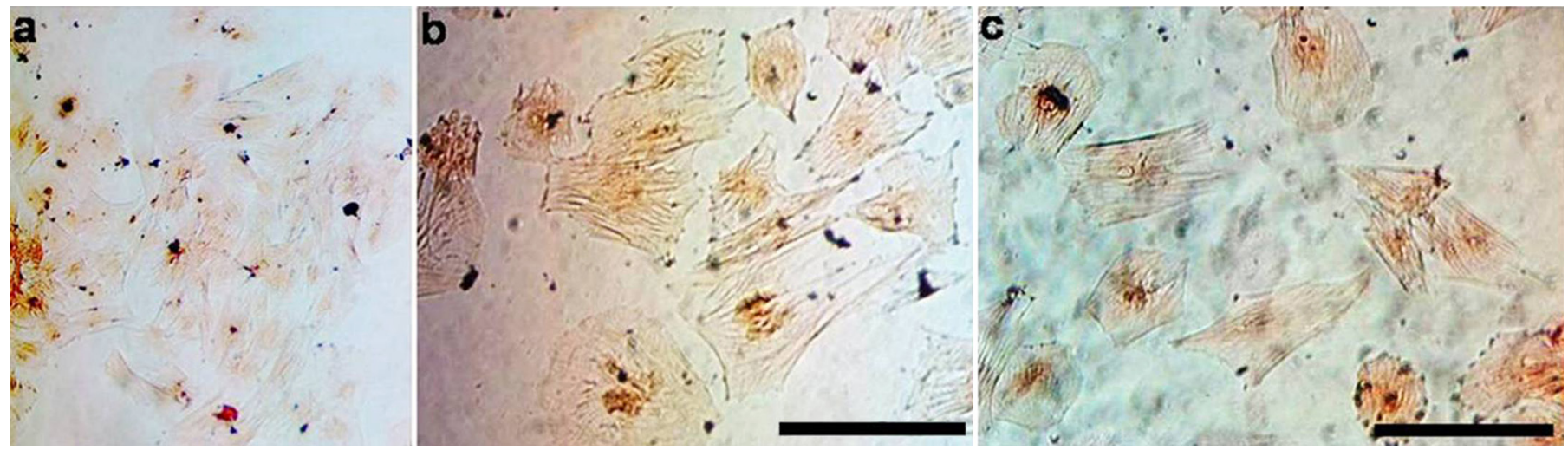

Fig.7. Final stage of osteogenic differentiation of progenitor cells isolated from agouti dental pulp. (a) Overview of differentiated osteoblasts. (b,c) A greater increase in a typical osteoblast in culture strongly marked by Alizarin Red staining. (a,b) Bars: $50 \mu \mathrm{m},(\mathbf{c})$ Bar: $100 \mu \mathrm{m}$.
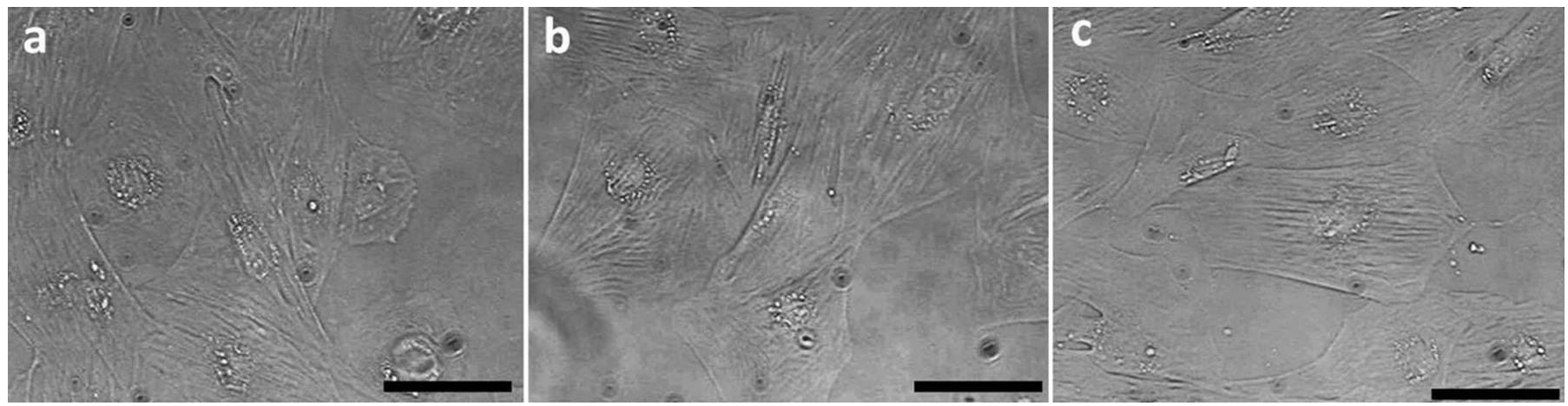

Fig.8. Final stage of adipogenic differentiation of progenitor cells from agouti dental pulp. (a-c) Presence of cells containing fat droplets dispersed in their cytoplasm, demonstrating sprawling to cuboid aspect. Bar: $25 \mu \mathrm{m}$.

thos et al. (2000) reported a highly clonogenic population present in the pulp tissue, showing cell colonies with typical fibroblastoid morphology.

Compared to human dental pulp, the pulp tissue of agou$\mathrm{ti}$, at the end of twelve days showed similar CFU's formation (Tamaki et al. 2012). However, the observation frequency of CFU's formation can vary widely in the literature. Gronthos et al. (2000) showed a variation of 22-70 colonies. This author has shown that colonies of cells of the pulp tissue appear with greater frequency compared to bone marrow cells. This is probably due to the difference between the two connective tissues, since tooth pulp is mostly composed of fibrous tissue, while in aspirated bone marrow the hematopoietic cells appeared in excess ( $>99 \%$ ) (Gronthos et al. 2000). Thus, the CFU's obtained in this study, when compared to the literature suggest that their efficiency is comparable to previous descriptions (Jo et al. 2007).

After plating to assess the proliferative capacity in culture, we observed that the samples tested demonstrated rapid growth, especially in the first 10 days of culture (third or fourth passages in culture). These cells were cultured in F12-DEMEM medium and, comparatively, no cellular morphologic changes before or after unfreezing were observed, with similar proliferation in culture that suggested similar functional behavior. Similarly, Liezier et al. (2012) observed proliferative behavior of stem cells in dental pulp culture, when conducting a pre and post-unfreezing comparative study for several culture media. These authors demonstrated that DEMEM-F12 allowed proliferative potential similar to non-frozen and post-cryopreservation cells without the induction of spontaneous differentiation. Tamaki et al. (2012) demonstrated that the proliferative potential of dental pulp stem cells in culture is more effective than the bone marrow aspirates. Cell cycle analysis compared to the growth curve showed that most of the population studied was in mitosis (Phase G2/M) in relation to stem cells from bone marrow, which were quiescent (Phase G0/G1). In a conjunctive evaluation, the results obtained for the proliferative and clonogenic potential of cells obtained from agouti dental pulp explants were similar to those previously reported in the literature (Kerkis et al. 2006, Alge et al. 2010, Suchánek et al. 2010).

Flow cytometry showed an immunoreactivity profile for the studied cultures by positive expression of specific markers for mesenchymal stem cells (CD34+, CD73+, CD90+, CD105+) and CD34+, which, although it represents the existence of a hematopoietic population, it has also been reported by other authors in immunophenotypic characterization of dental pulp stem cells (Laino et al. 2005). While positive for CD34 in expanded in culture stem cells, it clearly indicates their stromal origin because there was negative reaction for $\mathrm{CD} 45$, which recognizes the leukocyte common antigen, subsets of monocytes and $\mathrm{T}$ cells, reinforcing the idea that a population of hematopoietic cells is absent (Garcia-Pacheco 
et al. 2001). Laino et al. (2005) suggested that dental pulp stem cells are considered CD34+, since these cells also share Stro-1+ junction sites, also present in the population of dental pulp stem cells. CD73, CD90 and CD105 were expressed positively in the cultured stem cells from agouti dental pulp. These markers have been characterized for their positive expression in populations of mesenchymal stem cells (Dominici et al. 2006). For dental pulp stem cells, these markers have been described in numerous publications (Gronthos et al. 2002, Gronthos et al. 2003, Kerkis et al. 2006). The presence of CD73+, CD90+ and CD105+ cells and negative for CD14, CD45 and 79, mean that the method of cell selection and purification of the primary cultures established a primary cell lineage free of contamination by blood cells. Additionally, CD105, positively expressed in our cultures, is a marker commonly expressed by endothelial progenitors and has been correlated as a marker of multipotency, on its co-expression with CD133, suggesting the existence of lines of undifferentiated stem cells (Suchánek et al. 2010). The differentiation media tested (Stem cell Pro ${ }^{\circledR}$ kit) demonstrated potential to induce adipogenic and osteogenic differentiation of agouti dental pulp stem cells of agoutis. The protocol for media changes followed the criteria previously reported by Mambelli et al. (2009). Both the osteogenic and adipogenic differentiations were visualized by morphological changes observed for a phenotype similar to osteoblasts and adipocytes, respectively. For the former, the presence of positive staining by Alizarin Red showed the formation of mineralized extracellular matrix (Kerkis et al. 2006, Casagrande et al. 2010, Sakai et al. 2010). In fact, odontogenic and osteogenic progenitors, although distinct in their ontogenesis, contain similar characteristics for the expression of several proteins present in the extracellular matrix of bone and dentin (Olsen, Reginato \& Wang 2000). Morsczeck et al. (2005) discussed the immunomodulatory properties of dental pulp stem cells, and their potential to differentiate into odontoblasts, cementoblasts and osteoblasts. For adipogenic differentiation, the presence of a wide format showing fat granules inside (Miura et al. 2003), supported references in the literature which describe the commitment in stem cells from dental pulp to differentiate in adipogenic strains (Zhang et al. 2006).

\section{CONCLUSIONS}

Thus, taking into account all our findings, coupled with those previously published in the literature, we suggest that a population of cells isolated from explants of agouti dental pulp constitutes a representative sample of a population of stem cells, and that this species may constitute a biological model applied to the study of this cell niche and its use in regenerative therapies.

The kits for specific induction of adipogenic and osteogenic differentiation in humans have shown potential for inducing stem cells from agouti dental pulp.

Acknowledgements.- The authors thank the National Council for Scientific and Technological Development (CNPq), the Faculty of Veterinary Medicine, University of São Paulo (FMVZ/USP), and the Research Laboratory of Morphological Animal Science, CCA/UFPI, for support in the research.

\section{REFERENCES}

Agha-Hosseini F., Jahani M.A., Jahani M., Mirza-Dizgah I. \& Ali-Moghaddam K. 2010. In vitro isolation of stem cells derived from human dental pulp. Clin. Transplant. 24:23-28.

Alge D.L., Zhou D., Adams L.L., Wyss B.K., Shadday M.D., Woods E.J., Gabriel Chu T.M. \& Goebel W.S. 2010. Donor-matched comparison of dental pulp stem cells and bone marrow-derived mesenchymal stem cells in a rat model. J. Tissue Eng. Regen. Med. 4:73-81.

Assis-Neto A.C., Carvalho M.A.M., Melo M.I.V., Miglino M.A., Oliveira M.F. \& Mariana A.N.B. 2003. Fases do desenvolvimento e diferenciação testicular em cutias (Dasyprocta aguti) criadas em cativeiros. Braz. J. Vet. Res. Anim. Sci. 40:71-79.

Atari M., Barajas M., Hernández-Alfaro F., Gil C., Fabregat M., Padró E.F., Giner L. \& Casals N. 2011. Isolation of pluripotent stem cells from human third molar dental pulp. Histol. Histopathol. 26:1057-1070.

Azevêdo L.M., Carvalho M.A.M., Menezes D.J.A., Machado G.V., Sousa A.A.R. \& Xavier F.G. 2008. Distribuição intraparenquimal da artéria hepática em cutias (Dasyprocta sp, Rodentia). Braz. J. Vet. Res. Anim. Sci. 45:5-10.

Balic A. \& Mina M. 2010. Characterization of progenitor cells in pulps of murine incisors. J. Dent. Res. 11:1287-1292.

Balic A., Aguila H.L., Caimano M.J., Francone V.P. \& Mina M. 2010. Characterization of stem and progenitor cells in the dental pulp of erupted and unerupted murine molars. Bone 46:1639-1651.

Cabral R.M., Ferraz M.S., Rizzo M.S., Sousa F.C.A., Rodrigues N.M., Ibiapina P.B., Ambrosio C.E. \& Carvalho M.A.M. 2012. Kidney injury and cell therapy: preclinical study. Microsc. Res. Tech. 75:556-570.

Casagrande L., Demarco F.F., Zhang Z., Araujo F.B., Shi S. \& Nör J.E. 2010. Dentin-derived BMP-2 andodontoblastic differentiation of SHED. J. Dent. Res. 89:603-608.

Conde-júnior A.M., Fortes E.A.M., Menezes D.J., Oliveira L.L. \& Carvalho M.A.M. 2012. Morphological and morphometric characterization of agoutis' peripheral blood cells (Dasyprocta prymnolopha Wagler, 1831) raised in captivity. Microsc. Res. Tech. 75:374-378.

Dominici M., Le-Blanc K., Mueller I., Slaper-Cortenbach I., Marini F., Krause D., Deans R., Keating A., Prockop Di. \& Horwitz E. 2006. Minimal criteria for defining multipotent mesenchymal stromal cells: The International Society for Cellular Therapy position statement. Cytotherapy 8:315-317.

Fortes E.A.M., Carvalho M.A.M., Almeida M.M., Conde-Júnior A.M., Cruz N.E.A. \& Assis-Neto A.C. 2005. Aspectos morfológicos da tuba uterina de cutias (Dasyprocta aguti, Mammalia: Rodentia). Braz. J. Vet. Res. Anim. Sci. 42:135-142.

Garcia-Pacheco J.M., Oliver C., Kimatrai M., Blanco F.J. \& Olivares E.G. 2001. Human decidual stromal cells express CD34 and STRO-1 and a related bone-marrow stromal precursors. Mol. Hum. Reprod. 7:151-157.

Gronthos S., Brahim J., Li W., Fisher L.W., Cherman N., Boyde A., DenBerten P., Robey P.G. \& Shi S. 2002. Stem cell properties of human dental pulp stem cells. J. Dent. Res. 81:531-535.

Gronthos S., Mankani M., Brahim J., Robey P.G. \& Shi S. 2000. Postnatal human dental pulp stem cells (DPSCs) in vitro and in vivo. Proc. Natl Acad. Sci. 97:13625-13630.

Gronthos S., Zannettino A.C., Hay S.J., Shi S., Graves S.E., Kortesidis A. \& Simmons P.J. 2003. Molecular and cellular characterization of highly purified stromal stem cells derived from human bone marrow. J. Cell Sci. 116:1827-1835.

Jo Y.Y., Lee H.J., Kook S.Y., Choung H.W., Park J.Y., Chung J.H., Choung Y.H., Kim E.S., Yang H.C. \& Choung P.H. 2007. Isolation and characterization of postnatal stem cells from human dental tissues. Tissue Eng. 13:767-773.

Kadar K., Kiraly M., Porcsalmy B., Molnar B., Racz G.Z., Blazsek J., Kallo K., Szabo E.L., Gera I., Gerber G. \& Varga G. 2009. Differentiation potential of stem cells from human dental origin - promise for tissue engineering. J Physiol. Pharmacol. 60:167-175.

Karaoz E., Dogan B.N., Aksoy A., Gacar G., Akyuz S., Ayhan S., Genç Z.S., Yuruker S., Duruksu G., Demircan P.C. \& Sariboyaci A.E. 2010. Isolation and in vitro characterization of dental pulp stem cell from natal teeth. Histochem. Cell Biol. 133:95-112. 
Kerkis I., Kerkis A., Dozortsev D., Stukart-Parsons G.C., Massironi S.M.G., Pereira L.V., Caplan A.I. \& Cerruti H.F. 2006. Isolation and characterization of a population of immature dental pulp stem cells expressing OCT-4 and other embryonic stem cell markers. Cells Tissues Organs 184:105-116.

Laino G., D’Aquino R., Graziano A., Lanza V., Carinci F., Naro F., Pirozzi G. \& Papaccio G. 2005. A new population of human adult dental pulp stem cells: a useful source of living autologous fibrous bone tissue (LAB). J. Bone Miner. Res. 20:1394-402.

Lizier N.F., Kerkis A., Gomes C.M., Hebling J., Oliveira C.F., Caplan A.I. \& Kerkis I. 2012. Scaling-up of dental pulp stem cells isolated from multiple niches. PLosOne 7:1-12.

Mambelli L.I., Santos E.J., Frazão P.J., Chaparro M.B., Kerkis A., Zoppa A.L. $\&$ Kerkis I. 2009. Characterization of equine adipose tissue-derived progenitor cells before and after cryopreservation.Tissue Eng Part C Methods 15:87-94.

Menezes D.J.A., Carvalho M.A.M., Assis-Neto A.C., Oliveira M.F., Farias E.C., Miglino M.A. \& Medeiros J.X. 2003. Morfologia dos órgãos genitais externos do macho de cutia (Dasyprocta agouti Linnaeus, 1766). Braz. J. Vet. Res. Anim. Sci. 40:148-153.

Miura M., Gronthos S., Zhao M., Lu B., Fisher L.W., Robey P.G. \& Shi S. 2003. SHED: Stem cells from human exfoliated deciduous teeth. Cell Biol. 100:5807-5812.

Monteiro B.G., Seraim R.C., Melo G.B., Silva M.C.P., Lizier N.F., Maranduba C.M.C., Smith R.L., Kerkis A., Cerruti H., Gomes J.A.P. \& Kerkis I. 2009. Human immature dental pulp stem cells share key characteristic features with limbal stem cells. Cell Prolif. 42:587-594.

Morsczeck C., Götz W., Schierholz J., Zeilhofer F., Kühn U., Möhl C., Sippel C. \& Hoffnann K.H. 2005. Isolation of precursor cells (PCs) from human dental follicle of wisdom teeth. Matrix Biol. 24:155-165.
Olsen B.R., Reginato A.M. \& Wang W. 2000. Bone Development. Annu. Rev. Cell Dev. Biol. 16:191-220.

Otsu K., Kishigami R., Oikawa-Sasaki A., Fukumoto S., Yamada A., Fujiwara N., Ishizeki K. \& Harada H. 2012. Differentiation of Induced Pluripotent Stem Cells Into Dental Mesenchymal Cells. Stem Cells Dev. 21:11561164.

Rocha A.R., Alves F.R., Argolo-Neto N.M., Santos L.F., Almeida H.M., Carvalho Y.K.P., Bezerra D.O., Ferraz M.S., Pessoa G.T. \& Carvalho M.A.M. 2012. Hematopoietic progenitor constituents and adherent cell progenitor morphology isolated from black-rumped agouti (Dasyprocta prymnolopha Wagler, 1831) bone marrow. Microsc. Res. Tech. 75:1376-1382.

Sakai V.T., Zhang Z., Dong Z., Neiva K.G., Machado M., Shi S., Santos C.F. \& Nor J.E. 2010. SHED differentiate into functional odontoblast and endothelium. J. Dent. Res. 89:791-796.

Sloan A.J. \& Smith A.J. 2007. Stem cells and the dental pulp: potential roles in dentine regeneration and repair. Oral Diseases 13:151-157.

Sottile V., Thomson A. \& McWhir J. 2003. In vitro osteogenic differentiation of humam ES cells. Cloning Stem Cells 5:149-158.

Suchánek J., Víšek B., Soukup T., El-Din Mohamed S.K., Ivančaková R., Mokrý J., Aboul-Ezz E.H.A. \& Omran A. 2010. Stem cells from human exfoliated deciduous teeth: Isolation, long term cultivation and phenotypical analysis. Acta Medica, Hradec Králové, 53:93-99.

Tamaki Y., Nakahara T., Ishikawa H. \& Sato S. 2012. In vitro analysis of mesenchymal stem cells derived from human teeth and bone marrow. Odontol. 101:121-132.

Ulmer F.L., Winkel A., Kohorst P. \& Stiesch M. 2010. Stem Cells: prospects in dentistry. Schweiz. Monatsschr. Zahnmed. 120:860-872.

Zhang W., Walboomers X.F., Shi S., Fan M. \& Jansen J.A. 2006. Multilineage differentiation potential of stem cells derived from human dental pulp after cryopreservation. Tissue Eng. 12:2813-2823. 